\title{
Problems with Essentialism and Constructionism in Contemporary Geographical Studies of Religion
}

\author{
FUJIMURA Ken'ichi \\ Part-time Lecturer, College of Letters, Ritsumeikan University, Kyoto 603-8577, Japan
}

\begin{abstract}
In recent geographical studies of religion, essentialist and constructionist positions have coexisted, and dissension between them has grown. In addition, each approach contains inherent problems; essentialist geographers have tended to reify religion and religious spaces, and constructionist geographers have tended to insufficiently analyze how the religious spaces produced by social groups influence those groups. In this paper, I clarify trends of geographical studies of religion written by English-speaking and Japanese researchers and their problems based on such a dual perspective, and suggest a direction in order to improve them. First, I analyze theoretical trends in geographical studies of religion dividing between essentialism and constructionism, and make each problem clear. After that, I review some approaches which seek other positions in geographical studies of religion paying attention to mutual relationship between structure and agency or spaces and individuals. Finally, I suggest the way to bridge the gap between essentialist and constructionist and to improve their problems. It is, in short, exploration of both mutual relationships between spaces and social groups concerning religion, and their geographical characteristics.
\end{abstract}

Key words: geographical studies of religion, essentialism, constructionism, structure-agency debate, religious space

\section{Introduction}

Recent human geographers have paid attention to religion. For example, the special issue of Social \& Cultural Geography 3(1) in 2002 focused on "placing religion and spirituality in geography." Similarly, in 2004 and 2005, the Japanese publication The Historical Geography (217 and 218) addressed the historical geography of religious culture. Overall, the number of geographical studies focusing on religion has increased (Oda 2002: 23). However, as many geographers have noted, geographical studies of religion ${ }^{1}$ have frequently lacked a common realm, purpose, and method (Tuan 1976: 271; Sopher 1981: 510; Stump 1986: 1; Kong 1990: 360; Park 1994: 20-21; Matsui 2003: 1).

Nakagawa (2005: 4-9) argued that recent positions on sacred places can generally be divided along essentialist and constructionist lines. While the essentialist position is based on the assumption that religious beliefs have substance and that sacred places have reality, the constructionist position considered the god(s) to be a human creation and sacred places to be symbols of social constructs. Nakagawa pointed out worldwide trends of polarization behind two such positions. One is a trend mainly in the religious world toward return to essence, and another is a postmodern trend mainly in social science.

This dual perspective also frames the overall trends in studies of religious spaces. Essentialist and constructionist approaches have long differed in their examination of religion. Yet as described in greater detail below, the two positions have coexisted in recent geographical studies of religion, and dissension between them has grown. In this paper, I review and clarify trends in geographical studies of religion conducted by English-speaking and Japanese researchers, and suggest an approach that may prevent dissension between these two opposing paths. Essentialist and constructionist approaches to geographical studies of religion are first examined separately, and problems within each approach are analyzed. 
I then outline other approaches focused on the relationship between structure and agency. Finally, I suggest the way to improve the situation and problems of each position.

\section{The Essentialist Position}

Constructionists within the field of human geography have generally criticized the "essentialist" methods of humanists. Humanistic geography arose in the 1970s as a reaction against the positivist approach that included behavioral geography (Johnston 1997: 175-176). Humanistic geographers treat humans as individuals and appreciate individual subjectivities, feelings, and independence regarding space (Morikawa 2004: 17). This approach, however, has been criticized by later constructionist geographers. For example, Oshiro (1994: 173) contended that humanistic geographers have misidentified "place" as a collection of essential attributes rather than a site in which social relationships cross. By such an approach, Oshiro argued, essentialists risked reification of place; the viewing of place as static and stable could mask real differences in gender, class, and race (Oshiro 2001: 7).

Humanistic geography has influenced studies of religion. According to Tuan (1976: 272), the humanistic approach to religion could address the various manifestations of human desire for coherence in the world. This approach enables geographers to examine the structures of sacred spaces in which individuals perceive and experience religion. While geographers of religion agreed implicitly with Sopher's doctrine that geographers could not treat individual beliefs and religious experiences (Sopher 1967: 1), humanistic geography broke through this doctrine. An example of the humanistic approach to sacred space is the analysis of the medieval Gothic cathedral as a symbol of paradise (Tuan 1977: 114-116).

However, the humanistic approach may inadequately address contemporary religious spaces. In modern society, verbal symbols have progressively displaced material symbols such as church architecture; further, symbols themselves have lost much of their power because of the diversification of worth and meaning (Tuan 1977: 117). Additionally, because the sacred has lost its aura of transcendental otherness, the modern church has increasingly functioned as a social and service center (Tuan 1978: 94-95) ${ }^{2}$.

In Japan, the humanistic approach has been applied to studies of religious landscapes, particularly examinations of sacred places and religious buildings (Sasaki 1989; Yamaguchi 1997; Taira 2002). However, after recent criticism from constructionists, some humanistic geographers of religion have changed to constructionist approaches ${ }^{3}$.

The humanistic approach has declined. Yet, even excluding studies by humanistic approach, we can find some studies examining religious thought or sacredness considered to be able to influence individuals, societies, and spaces directly, or examining direct influence of religious thought or sacredness on individuals, societies, and spaces. In this paper, I call such studies essential.

For example, Slater (2004) incorporated autobiography to discuss his identity as a Christian and his experience "encountering God". Nakagawa (2005: 10-52) discussed how North American Protestants developed a regional proselytization strategy based on their ideology. He also noted that modern geography had discarded teleology and regional substantialism. Despite such trends in academic geography, individuals with religious values based on teleological cosmology have actually created regions through their behavior (Nakagawa 2005: 31).

Abe (2000) studied the ways in which a number of religions, beliefs, and ideologies (including animism, Christianity, and modernism) perceive the world and divided these perceptions into some patterns.

Matsui (2003: 231-261) used immanent interpretation to describe the establishment of Jiba, the sacred place of Tenrikyo which was a "new" religion founded by Miki Nakayama in 19th century Japan. The immanent interpretation approach, which has been used in studies of comparative religion in Japan, sympathetically seeks to understand the religious experiences of individuals (Shimazono 1992b; Otani 1995). First, Matsui examined Nakayama's mental process of getting awareness of her calling as a saviour and acquisition of charismatic character. Second, Matsui clarified the process by which leaders of 
Tenrikyo organization gave Jiba the sacred meaning. As described by Matsui, after the death of Nakayama, the leaders relocated her charisma to the site where her house was. This site was regarded as the sacred place (Jiba) where Nakayama's charisma and the Tenrikyo organization would continue to exist.

The experiential physical interpretation, an approach similar to the immanent interpretation, has also been used in studies of comparative religion in Japan. Like the immanent interpretation, this approach has a sympathetic attitude toward believers. Yet, in contrast to the immanent interpretation, the experiential physical interpretation also requires participation in spiritual experiences by researchers.

Kamata, an advocate of seisin chirigaku (spiritual geography), is one practitioner of the experiential physical interpretation ${ }^{4}$. Kamata (1990) sought to understand the religious cosmology of various Japanese thinkers (e.g., Norinaga Motoori and Atsutane Hirata) sympathetically through their texts about geographical ideologies. Moreover, he visited the sacred places within and outside of Japan, and tried to understand religious cosmology by his mysterious experiences in these places (Kamata 1990, 1999).

As Kamata (1990, 1999) suggested, religious cosmology often has close relationships not only with institutional religion but also with traditional Japanese folk culture. For example, Iwahana (1983) and Oda (1989) analyzed cosmology of mountain beliefs. Yagi (1998) and Oguchi (2002: 105-119) investigated cosmology within villages and folk rituals. Abe (1995) interpreted cosmology as the basic "ways to perceive the world" and focused on Japanese cosmology from the phenomenological viewpoint. Sasaki (2003) examined cosmology of legends, myths, and folktales from a geographical perspective.

A number of studies on the relationships between religion and natural environment in Japan have also attempted to understand religious cosmology immanently. For example, Sonoda, a scholar of comparative religion and a Shinto priest, regarded fudo (climate) as an element of nature that was objectified by human beings (Sonoda 1990: 333-346) with reference to Watsuji (1979 [1935]: 9-28). Sonoda immanently explored the relationship between Shinto and climate in Japan. Sonoda suggested that the locations and forms of village Shinto shrines represented the order within village societies and that some mountains, forests, and rocks had sacred meanings associated with these shrines. Sonoda (1995) termed such worship based on inter-subjective concepts of natural environment "fudo saishi" (climatic worship) and found wisdom in the coexistence between humans and natural environment inherent in fudo saishi. Similar critiques of the materialism of modern society have been presented by Nagano (1989, 1990, 1992a, b, 1995, 1998), who examined how mountain beliefs have led to environmental preservation; Nomoto (1990), who explored Japanese folk views of sacred places through analyses of sacred landforms; and researchers of shasougaku, rising interdisciplinary studies of forests in shrines (Ueda and Ueda 2001; Ueda 2004).

Suzuki (1999) critiqued modern values but also criticized past studies that emphasized the harmony and order between religion and nature. Suzuki suggested that the concepts of "religion" and "natural environment" are cultural products of Western society and attempted to improve human-centered perception of nature.

Numerous Anglophone geographers have also studied the relationships between religion and nature. Historically, Western geography of religion has focused on describing the relationships between religion and natural environment (Matsui 2003: 5-7). Especially, a large number of studies referred to the influence of the natural environment on the establishment and development of religion. Many geographers of the early 20th century adopted environmental determinism (Kong 1990: 357-359). For example, Semple (1911) regarded landforms as important determinants of the characteristics of religion. According to Semple, monotonous desert and highland landscapes led to monotheistic beliefs (Semple 1911: 1, 511-515). Huntington (1945: 281-306) also linked regional climates to religious and cultural "evolution" ${ }^{5}$. After World War II, however, many geographers, including Isaac $(1960,1962)$, began to emphasize the possibilities natural environment offered religion. Some geographers, including Sopher (1967: 1-46), also insisted that researchers address the mutual re- 
lationships between religion and natural environment. Whether or not, these researchers tended to seek essential characteristics of each religion. Unlike Suzuki (1999), they hardly considered religion to be social constructs.

Some researchers studying the relationships between religion and society also tended to find essential characteristics of each religion. For example, Suizu (1959), Uchida (1971: 209-243), and Nakagawa $(1983,1991)$ examined the influence of religious characteristics of Christian/Buddhist denominations on regional social structures.

These researchers had interest in the religious thought or sacredness and their influence on societies and spaces. Thus, these researchers generally did not tend to regard religion as a mere social phenomenon. However, if religion can be seen as a kind of cultural phenomenon (Kishimoto 1961: 17), and if culture can be seen as a lifestyle learned and handed down by the members of a society (Yoshida 1987), the religion will mean a kind of social phenomenon. Constructionist geographers might blame the essentialist studies of culture (including religion) for reifying "culture" (Mitchell 1995). Therefore, the next section analyzes constructionist trends and related problems within geographical studies of religion.

\section{The Constructionist Position}

Constructionism focuses on the processes by which meaning is socially constructed. Constructionist approaches are diverse, reflecting various ideologies and theories ${ }^{6}$. If the constructionism is interpreted broadly, most contemporary studies of cultural and social geography will be regarded as constructionist. Therefore Ohira (2003: 73-74) recommended that only studies analyzing the discourse used in processes of construction should be regarded as constructionist. However, as indicated in the previous section, not all geographical studies of religion necessarily view religious spaces as socially constructed. Nakagawa (2005: 6) viewed constructionist studies as those that regarded sacred places as socially constructed symbols. A similar view is adopted in this paper: the constructionist researchers regard religious thought and sacred- ness as notions constructed and given to spaces by social groups, and examine them as the studies of relationships among social groups or relationships between social groups and spaces. In their studies, it is not religious thought or sacredness but a space or a social group that is able to influence a social group directly. Religious thought and sacredness are able to influence a social group just indirectly. Thus, constructionist researchers deal with religious thought and sacredness functionally. These researchers treat religious thought and sacredness (as well as nationalism and commercialism) as some kinds of ideologies. They have interest not in essential characteristics of these ideologies but in the way social groups use these ideologies.

The constructionist perspective emerged in the 1970s in Anglophone studies on the political uses of religious spaces. For example, Harvey (1979) examined how the process of building the Sacré-Coeur Basilica became etched in the memory of sacrifices of the Paris Commune by the materialist concept of history. Duncan (1985) analyzed a visit to the Buddhist temple by the President of Sri Lanka, and pointed out the ideological use of Buddhism by the state.

In recent years, "new" cultural geography approaches have greatly influenced constructionist studies of religious spaces. In the latter half of the 1980s, some geographers advocated a "new" cultural geography guided by cultural studies (Cosgrove and Jackson 1987; Jackson 1989). These studies and others like them criticized humanistic geography and the Berkley school of cultural geography; instead, the "new" approach emphasized a materialist framework in which culture reflected the relationships of production. Case studies clarified the social factors involved in the formation of spaces, especially factors such as ethnicity, class, and gender; the processes by which social groups produced specific spaces were thereby analyzed. However, few researchers considered religion to be one of the main production factors.

Concurrently, some geographers of religion began to propose that geographical studies must also include analyses of religion in the context of social relationships. For example, Levine (1986) proposed that geographers should understand religious institutions in terms of social 
class. Using "new" cultural geography as a framework, Kong presented a variety of spatial factors associated with religion. Kong, whose studies have originally focused on "new" cultural geography, applied those concepts to her later studies of religion. Since the latter half of the 1980s, Kong has elucidated the political processes that shape the social production of spaces and their meanings by analyzing letters, popular music, and urban/rural landscapes (Fujimura 2004: 72). Her analyses have included notions of ethnicity, class, gender, heritage, nationalism, identity, colonialism, commercialism, and hegemony within the general framework of the "new" cultural geography advocated by Cosgrove and Jackson (Kong 1997).

Kong has considered religious spaces, as well as other spaces, to be social constructs and has analyzed the processes of spatial production. Although other researchers of "new" cultural geography have tended to place greater emphasis on factors such as ethnicity, class, and gender, Kong (2001a) has contended that religion is also a key factor. From reviewing studies available in the 1990s, she suggested four themes related to the "new" geographies of religion: (1) politics of space, (2) poetics of place, (3) poetics of community, (4) politics of identity and community. Her terms of "politics" and "poetics" mean situational and substantial sacred.

According to Kong (2001a: 212-224), researchers of politics of spaces analyze conflicts over sacred spaces focusing on secular-religious and majority-minority relationships. The poetics of sacred places are an important part of peoples' experience of the religious, and are often discussed separately from the politics of religion. Yet she required researchers of this theme to notice the sacralization process from the viewpoint of politics. She blamed humanistic researchers including Tuan for a lack of awareness that the attachments with the sacred places were created through sacred place-making. Researchers of poetics of religious communities often regard religious buildings as social centers of them. Yet she also required researchers of this theme to notice internal tension within these communities from the viewpoint of politics. And researchers of politics of religious identities and communities focus on conflicts between/within communities given by "intolerance of difference".

Kong (2001a: 224-225) did not interpret four themes as unconnected with each other, and noticed the intersections between the politics and poetics of religious place, identity, and community. She suggested that the way to bridge politics and poetics was through analyses of how the poetics of places were shaped by/amid political relationships. In short, her "new" geographies of religion are based on the political assumption that sacred space is contested space (Kong 2001a: 213). Such an assumption is shared with her case studies.

Since the 1990s, Kong has published case studies examining differences in attitudes of the state, religious groups, and religious adherents toward religious spaces in Singapore. For example, Kong (1993a,b, 1996) and Kong and Yeoh (2003: 75-93) have examined conflicts over the construction and preservation of religious buildings. As she described, the Singapore government has provided religious groups with land to erect religious buildings and has at times required these groups to relocate based on urban planning decisions. Yet, religious buildings deemed to be of historical and architectural value and gazetted as national monuments are preserved. The government develops such policies in an attempt to use scarce land rationally, to increase morality by supporting religion, and to promote the tourist industry. Kong described the national policies and the responses of religious groups that saw such policies as ideological hegemony by the state and the resistance/adaptation of the people involved. Moreover, Tong and Kong (2000) described how adherents of "Chinese religion" 7 transformed their rituals to adapt to modern apartments standardized by the state; the paper focused on how adherents negotiated the modernization of their lives within a context of state hegemony. Further, Kong (2002a) examined the "unofficially sacred" house churches used by Christian groups that had not been provided lands for their churches.

A number of other Anglophone geographers have also analyzed religious spaces from the viewpoint of "new" cultural geography. Livingstone et al. (1998) revealed the social diversity of religious spaces in Belfast through an exten- 
sive survey of Protestant and Catholic churchgoers. The special issue of Social \& Cultural Geography 3(1) described above also contained studies of religious buildings. For example, Raivo (2002) described the rebuilding of a Finnish Orthodox Church as a process linked to national heritage. Naylor and Ryan (2002) detailed notions of similarity and difference employed in the discourse of mosque users, other local residents, the press, and local/central governments in relationship to a London mosque. MacDonald (2002) analyzed spatial changes in worship in a Presbyterian church in Scotland through the following conceptual triad related to spatial production (Lefebvre 1991): spatial practices, representations of space, and representational space.

Recently, many geographers in Japan have interpreted the production of and changes in sacred places, pilgrimages, and graveyards by focusing on relationships among social groups and their change dynamically (Shimazu 1990; Imazato 1995; Ohira 1996; Oshiro 1992, 1998; Mori 2001a, b, 2002a,b). Studies by Oshiro and Mori have particularly incorporated the "new" cultural geography perspective. Oshiro (1992, 1998) analyzed the processes by which kin, worshippers, and governments have shaped ritual facilities and related discourse in Okinawan villages. Mori (2001a, b, 2002a, b) clarified the processes by which Buddhist denominations, pilgrim associations, governments, and the mass media have produced sacred places, routes, and travel associated with the Henro pilgrimage of Shikoku Island, Japan.

The constructionist trend in geographical studies of religion has grown stronger, reflecting the rise of "new" cultural geography. Yet, a number of issues remain within constructionist studies. First, these studies may insufficiently address how the religious spaces produced by social groups then influence those groups. ${ }^{8}$ As noted by Holloway and Valins (2002), religion and spirituality are central to the everyday lives of vast numbers of individuals, and the place of religion and spirituality is of central importance and significance to many people. Therefore, researchers cannot ignore the influence of religious spaces on individuals and social groups. If researchers examine the relationships between religious spaces and social groups, not as static but as a dynamic process by which social groups produce religious spaces, then the processes by which these religious spaces then influence the social groups that created them must also be addressed. In short, the mutual relationships between religious spaces and social groups must be discussed.

Second, constructionist researchers face the challenge of understanding religious beliefs from a materialist viewpoint. Slater (2004) criticized the constructionist geographers praised by Kong (2001a) for approaching religious experiences only as outsiders. Some other Christian geographers, including Clark (1991) and Pacione (1999), blamed postmodernism for contributing to materialism and a lack of morality. Indeed, Kong's discussions emphasizing religion as well as the other social factors from the materialist viewpoint are somewhat paradoxical. In Japan, Kawai (2001: 350) and Nakagawa (2005: 8) criticized constructionist studies from the humanistic perspective for disregarding the meanings and realities of sacred places among believers. Matsui (2005: 168) stressed the importance of sympathetically understanding the "spirit of place" (spiritual quality) of sacred sites as well as the processes by which various human agents created and experienced these sacred sites.

\section{Exploration of Other Positions}

As outlined above, dissension among recent geographical studies of religion has grown, for essentialist and constructionist positions are emerging in these studies. Therefore, other approaches are necessary to prevent further gap.

First, the mutual relationships between structure and agency or spaces and individuals should be reviewed. The structuration theory, which was developed in the latter half of the 1970s and focuses on the interactions between structure and agency, was expected to act as a "middle theory" between Marxist geography focusing on structure and humanistic geography focusing on human agency (Morikawa 2004: 18-19). And "new" regional geographers have applied the structuration theory to their studies (Johnston 1997: 247-250). In geographical studies of religion, some researchers have also tried to apply this perspective. 
For example, Cooper (1992) regarded the exploration of "religio-geographical reciprocity" between place/landscape interpretation and religious experience as a new direction in the geography of religion. Cooper proposed that researchers could clarify religio-geographical reciprocity by analyzing social and material relationships, texts, and symbols. Wilson (1993) noted that Cooper's views reflected modes of inquiry that seek to connect the dualism of people-place and agent-structure and tend toward the eclecticism of hermeneutics and materialism. Wilson also criticized Cooper's discussion that there has been a lack of concrete inquiry into how space as a social product affects the construction of religious beliefs and practices.

Park (1994: 23-25) regarded the structureagency debate (as well as humanism and postmodernism) as a promising context within studies of geography and religion; however, Park noted that only a few studies of geography and religion had applied this debate.

Thus, since the 1990s, some researchers have tried to incorporate the mutual relationship between structure and agency or space and individuals into theories of religious spatiality. Yet, unlike humanism and postmodernism, this perspective had been applied to few case studies since that time.

In 2000, however, Stump attempted to incorporate the "new" regional geographical and structuration theories into geographical studies of religion in his book Boundaries of Faith (Stump 2000). Until the 1990s, Stump mainly examined the distribution of religions by statistical methods including logistic regression analysis ( $\mathrm{Fu}-$ jimura 2004: 75), yet his book intended to clarify the geographical characteristics of religious fundamentalism.

Stump (2000: 1-14) defined the concept of "religious fundamentalism" as the response of religious traditionalists to contemporary social and global trends, including modernism, secularism, cultural pluralism, colonialism, and imperialism. And he aimed to clarify the diverse characteristics and impacts of religious fundamentalism through geographical concepts of "contextuality" and "geographical character".

According to Stump (2000: 15), the diversity of religious fundamentalism is a product of di- alectical interactions between global forces and local contexts. His argument was based on the perspectives of Massey (1984), a "new" regional geographer who suggested that the local characteristics operated on the general processes to produce a specific outcome in each place (Massey 1984: 9).

Stump (2000: 16-17) also considered local contexts to be main factors in the diversity of religious fundamentalism. He supported this argument with discussions by Dear and Wolch (1989) and Hauer (1990) about "locale" which is one of main notions of the structuration theory. Namely, varying circumstances lead to the development of unique religious locales within which interactions between fundamentalists and the rest of the society both shape and are shaped by local/social conditions and cultural characteristics. In each of these circumstances, the development of fundamentalism is affected differently by local/social structures and power relationships (Stump 2000: 16-17).

From this perspective, Stump (2000: 15) posed two main themes: the role of geographical context in the development of diverse forms of religious fundamentalism in different parts of the world, and the relevance of territoriality and related geographical concepts in understanding the varied ways in which religious fundamentalists define their identities, express their beliefs, and implement strategies for restoring order to the world. Stump used case studies of fundamentalism in North American Protestant, Jewish, Islamic, Sikh, and Hindu communities.

Stump successfully avoided the essentialist perspective by regarding religious fundamentalist movements as social and cultural phenomena shaped by local circumstances. Further, he not only emphasized the social construction of fundamentalist movements but also revealed the processes by which fundamentalist ideologies have shaped local conditions and cultural characteristics through interactions among social groups. Thus, Stump helped clarify the mutual relationships between religious movements and local conditions by using ideological and constructionist approaches.

However, Stump did not reexamine the research framework suggested in the initial pages by the results of case studies in his book. For ex- 
ample, he had not shown concretely what the "religious locales" were. Kong (2002b) thus criticized Stump for avoiding deeper theoretical discourse.

As Kong (2002b) noted, it is difficult to consider Stump's theories as established. In addition, the main objects of Stump's research were not religious spaces, which were main objects of geographical studies of religion (Matsui 2003: 27), but religious movements. However, it is meaningful for geographers of religion to examine Stump's perspective, particularly his analysis of the geographical aspects of religious movements and focus on dialectical interactions between global trends and local contexts and the mutual relationships between religious movements and local/social conditions. Such a perspective can be applied to analyses of the mutual relationships between religious spaces and social groups, which constructionist geographers including Kong may insufficiently analyze. Studies of religious spaces should try to apply Stump's perspective more widely and refine his perspective by analyzing case studies.

\section{Conclusions}

Described above, essentialist and constructionist positions have coexisted in recent geographical studies of religion, and dissension between them has grown. In addition, each position contains inherent problems. Essentialist geographers have tended to reify religion and religious spaces. In contrast, constructionist geographers have tended to insufficiently analyze how the religious spaces produced by social groups influence those groups. Moreover, some geographers have criticized constructionists for their neglect of understanding the meanings and realities of religious experiences and sacred places held by believers. Stump's discussion of the geographical characteristics of religious movements with a focus on dialectical interactions between global trends and local contexts and the mutual relationships between religious movements and local/social conditions is useful in resolving the problems of constructionist and essentialist approaches and the gap of them.

Geographical researchers would benefit from applying such perspectives to analyses of religious spaces, including sacred places and religious buildings. It is necessary to clarify the mutual relationships between religious spaces and social groups. According to Matsui (2003: 27), religious spaces have two aspects: empirically-grasped aspect (e.g., distribution of religious buildings) and symbolically-told aspect (e.g., religious cosmology). The dynamic processes by which social groups form such aspects of religious spaces and the processes by which religious spaces influence these groups must be examined in terms of both global trends and local contexts. By examining these processes, geographical studies can effectively clarify the mutual relationships between religious spaces and social groups and their respective geographical characteristics.

Researchers can solve the problems of essentialist studies by regarding religious spaces as the products of social groups. In addition, researchers must analyze the processes by which religious spaces influence these groups. After these analyses, researchers can identify the mutual relationships between religious spaces and social groups. In these analyses, researchers should also examine how the religious cosmology of believers influences social groups through their own behavior. By this approach, researchers can also overcome the shortcomings of constructionist studies.

However, future research should also place religious cyberspaces in the framework of studies of mutual relationships between religious spaces and social groups. In the past, physical spaces were indispensable to organized religious groups. Buildings, including churches, temples, and mosques, were the base for group activities (Morioka 1973: 305). However, "cyber religion", acting mainly in cyberspaces; appears in recent years (Kurosaki 2005). The appearance of such new religions may undermine past ways of understanding the relationships between spaces and religious groups.

Kong (2001b) sought to relate religious cyberspace to "new" geographies of religion using her four themes. Some other researchers have also conducted case studies of Websites and computer-mediated communication (CMC) related to religion. For example, Enomoto (2003) analyzed the bulletin board system (BBS) of a Japanese Website administered by representa- 
tives of a "new spiritual culture" 9 group. Enomoto suggested that in contrast to traditional organized denominations, most new spiritual culture groups have no physical spaces for intercommunication. Members of these groups substitute CMC for physical bases to create solidarity among the members.

In contrast, few traditional denominations in Japan have a BBS on their official Websites (Enomoto 2003: 67). Such denominations more often use their Websites to inform adherents and tourists of their facilities or to support their activities in physical spaces (Kurosaki 2000a; Fukamizu 2000). Geographers must thus continue to empirically examine, including through fieldwork, how new relationships between cyberspaces and social groups concerning religion are different from traditional relationships between physical spaces and social groups ${ }^{10}$.

\section{Acknowledgements}

This paper is a revision of Chapter 1 of my doctoral dissertation submitted in March of 2005. I thank the dissertation committee (Prof. Nobukiyo Eguchi, Prof. Hirofumi Katahira, and Prof. Kazuhito Kawashima) and the other members of the Department of Geography, Ritsumeikan University, Kyoto, Japan, for their kind and helpful advice.

(Received 25 November 2005) (Accepted 6 February 2006)

\section{Notes}

1. As described below, not only geographers of religion but also various other researchers, including "new" cultural geographers, have recently analyzed religious spaces. Therefore, in this paper, I refer to all geographical studies of religious spaces as "geographical studies of religion".

2. Tuan (1978) noted that the distinction between the sacred and the secular is often fuzzy; he thus investigated the sacred in nation states, suburbs, and neighborhoods rather than in recent churches.

3. For example, Yasuyo Kawai (née Yamaguchi) used a humanistic approach to examine the landscapes of sacred places (Yamaguchi 1997). Recently, however, she converted to a constructionist position (Kawai 2004).

4. However, Kamata (1992: 129) questioned the validity of the distinction between the immanent in- terpretation and the experiential physical interpretation.

5. Huntington (1945: 292-293) disagreed with "the extreme determinist" view that a specific environment obliges people to adopt a specific kind of religion. He suggested that environment may limit the characteristics of religions to a certain extent because generally speaking, people react differently in different places.

6. According to Burr (1995: 1-8), the social constructionist approach is that which adopts more than one of the following seven points: (1) antiessentialism, (2) anti-realism, (3) historical and cultural specificity of knowledge, (4) language as a pre-condition for thought, (5) language as a form of social action, (6) a focus on interaction and social practices, (7) a focus on processes.

7. According to Tong and Kong (2000: 31), Chinese religion is a kind of syncretism which incorporates elements of Confucianism, Taoism, and Buddhism as well as ancestor worship, and other elements of animistic folk religions.

8. Recently, Mori (2005) analyzed how audiences received a Buddhist exhibition presented by denominations, the press, and other groups. However, his analysis depended for data on articles of a newspaper which was one of the presenters, and thus lacked persuasiveness.

9. The new spiritual culture means a religious culture or movements by loose-knit collectives made up of individuals who want to develop their own spirituality. It includes Western "New Age" and Japanese "seishin sekai (spiritual world)" (Shimazono 1992a: 234-240, 1996: 46-53).

10. Empirical research on religion-themed CMCs requires not only analyses of information distributed through this media but also the incorporation of multiple approaches, including participant observation and interviews (Tamura 1999: 36-37; Kurosaki 2000b: 90-91).

\section{References}

Abe, H. 1995. Nihon kukan no tanjou: Cosmology, fukei, takaikan (The birth of Japanese space: Cosmology, landscape, and the view of hereafter). Tokyo: Serica Shobo. (J)

Abe, H. 2000. Kukan no hikaku bunkashi (The cross-cultural history of spaces). Tokyo: Serica Shobo. (J)

Burr, V. 1995. An introduction to social constructionism. London: Routledge.

Clark, M. 1991. Developments in human geography: Niches for a Christian contribution. Area 23: 
339-345.

Cooper, A. 1992. New directions in the geography of religion. Area 24: 123-129.

Cosgrove, D. and Jackson, P. 1987. New directions in cultural geography. Area 19: 95-101.

Dear, M. and Wolch, J. 1989. How territory shapes social life. In The power of geography: How territory shapes social life, ed. J. Wolch and M. Dear, 3-18. Boston: Unwin Hyman.

Duncan, J. S. 1985. Individual action and political power: A structuration perspective. In The future of geography, ed. R. J. Johnston, 174-189. London: Methuen.

Enomoto, K. 2003. CMC (computer mediated communication) on religious Websites: A comparison of the Websites of an organized religion and a new spiritual movement. Annual Review of Religious Studies (The University of Tokyo) 21: 67-83. (JE)

Fujimura, K. 2004. Recent trends in the Anglophone geographical studies of religion: Approaches by L. Kong and R. W. Stump. The Journal of Ritsumeikan Geographical Society 16: 71-80. (J)

Fukamizu, K. 2000. The ability of the Website of religion: The case of the temples and churches in Hiroshima. Religion \& Society 6: 47-60. (J)

Harvey, D. 1979. Monument and myth. Annals of the Association of American Geographers 69: 362-381.

Hauer, J. 1990. What about regional geography after structuration theory? In Regional geography: Current developments and future prospects, eds. R. J. Johnston, J. Hauer, and G. A. Hoekveld, 85-102. London: Routledge.

Holloway, J. and Valins, O. 2002. Editorial: Placing religion and spirituality in geography. Social \& Cultural Geography 3: 5-9.

Huntington, E. 1945. Mainsprings of civilization. New York: John Wiley and Sons.

Imazato, S. 1995. Rural religious landscape constituents and social structure: A case study of a mountain village, Shiga Prefecture. The Human Geography 47: 458-480. (JE)

Isaac, E. 1960. Religion, landscape and space. Landscape 9: 14-18.

Isaac, E. 1962. The act and the covenant: The impact of religion on the landscape. Landscape 11: 12-17.

Iwahana, M. 1983. Shukyo keikan no kozo haaku eno iti siron: Tateyama no engi, mandala, sankei ezu karano approach (An attempt to understand structure of religious landscape: An approach based on the history, mandala, and pictorial map for pilgrims to Tateyama). In Kukan, keikan, image (Space, landscape, and image), ed. Department of Geography, Kyoto University, 163-185. Kyoto: Chijin Shobo. (J)

Jackson, P. 1989. Maps of meaning: An introduction to cultural geography. London: Unwin Hyman.

Johnston, R. J. 1997. Geography and geographers: Anglo-American human geography since 1945, 5th ed. London: Arnold.

Kamata, T. 1990. Basho no kioku (Memory of place). Tokyo: Iwanami Shoten. (J)

Kamata, T. 1992. Michi to shiteno gakumon (Learning as Michi). In Ima shukyo wo dou toraeruka (How to understand religion now?), ed. Shukyo Shakaigaku Kenkyukai, 127-131. Tokyo: Kaimeisha. (J)

Kamata, T. 1999. Seichi eno tabi: Seisin chirigaku kotohajime (Journeys to sacred places: Introduction to spiritual geography). Tokyo: Seikyusha. (J)

Kawai, Y. 2001. Mt. Fuji as a sacred site: On historical change in Fuji-kou and Fuji-zuka in the 23 wards of Tokyo. Geographical Review of Japan 74A: 349-366. (JE)

Kawai, Y. 2004. The method to reconstruct "the sacred landscape" constructed by the social community. The Historical Geography 217: 50-64. (JE)

Kishimoto, H. 1961. Shukyogaku (Comparative religion). Tokyo: Taimeido. (J)

Kong, L. 1990. Geography and religion: Trends and prospects. Progress in Human Geography 14: 355-371.

Kong, L. 1993a. Ideological hegemony and the political symbolism of religious buildings in Singapore. Environment and Planning D: Society and Space 11: 23-45.

Kong, L. 1993b. Negotiating conceptions of sacred space: A case study of religious buildings in Singapore. Transactions of the Institute of British Geographers. New Series 18: 342-358.

Kong, L. 1996. The commercial face of God: Exploring the nexus between the religious and material. $\mathrm{Ge}$ ographia Religionum 10: 123-141.

Kong, L. 1997. A "new" cultural geography? Debates about invention and reinvention. Scottish Geographical Magazine 113: 177-185.

Kong, L. 2001a. Mapping "new" geographies of religion: Politics and poetics in modernity. Progress in Human Geography 25: 211-233.

Kong, L. 2001b. Religion and technology: Refiguring place, space, identity and community. Area 33: 404-413.

Kong, L. 2002a. In search of permanent homes: Singapore's house churches and the politics of space. Urban Studies 39: 1573-1586. 
Kong, L. 2002b. Review of Boundaries of faith: Geographical perspectives on religious fundamentalism by R. W. Stump. Progress in Human Geography 26: 286-287.

Kong, L. and Yeoh, B. S. A. 2003. The politics of landscapes in Singapore: Constructions of "nation". Syracuse: Syracuse University Press.

Kurosaki, H. 2000a. The social context of Internet usage among Japanese religions. Transaction of the Institute for Japanese Culture and Classics 85: 579-592. (J)

Kurosaki, H. 2000b. Gendai no media communication ni okeru shukyoteki kyodosei: Kirisutokyokei mailing list no baai (Religious combination in the contemporary media communication: A case of a Christian mailing list). In Constructing belief, ed. E. Otani, T. Kawamata, and H. Kikuchi, 86-109. Tanashi: Harvest-sha. (J)

Kurosaki, H. 2005. Cyber religion. In Dictionary of modern religion, ed. N. Inoue, 168-169. Tokyo: Kobundo. (J)

Lefebvre, H. translated by Nicholson-Smith, D. 1991. The production of space. Oxford: Blackwell.

Levine, G. J. 1986. On the geography of religion. Transactions of the Institute of British Geographers. New series 11: 428-440.

Livingstone, D., Keane, M. and Boal, F. 1998. Space for religion: A Belfast case study. Political Geography 17: 145-170.

MacDonald, F. 2002. Towards a spatial theory of worship: Some observations from Presbyterian Scotland. Social \& Cultural Geography 3: 61-80.

Massey, D. 1984. Introduction: Geography matters. In Geography matters! A reader, ed. D. Massey and J. Allen, 1-11. Cambridge: Cambridge University Press.

Matsui, K. 2003. Nihon no shukyo kukan (Religious spaces in Japan). Tokyo: Kokon-shoin. (J)

Matsui, K. 2005. Problems of managing sacred sites in terms of tourism. Studies in Human Geography (University of Tsukuba) 29: 159-169. (JE)

Mitchell, D. 1995. There's no such thing as culture: Towards a reconceptualization of the idea of culture in geography. Transactions of the Institute of British Geographers. New Series 20: 102-116.

Mori, M. 2001a. Contemporary religious meaning of the pilgrimage route. The Human Geography 53: 173-189. (JE)

Mori, M. 2001b. Authority and sacredness of place. Geographical Science 56: 252-271. (JE)

Mori, M. 2002a. Representing and consuming Henro pilgrimage on Shikoku island. The Journal of the Literary Association of Kwansei Gakuin University 51(4): 160-173. (J)
Mori, M. 2002b. Spatial formation and change in the Henro pilgrimage in modern Japan. The Human Geography 54: 535-556. (JE)

Mori, M. 2005. Reviving nationalism by articulation of the Priest Kobo-daishi and Japanese culture. Geographical Review of Japan 78: 1-27. (JE)

Morikawa, Y. 2004. Development of human geography since 1945: A comparative study between English and German-speaking countries. Tokyo: Kokon-shoin. (J)

Morioka, K. 1973. Shukyo shudan (Religious group). In Shukyogaku jiten (The dictionary of comparative religion), ed. I. Oguchi and I. Hori, 305-310. Tokyo: University of Tokyo Press. (J)

Nagano, T. 1989. Nature preservation in based on the Japanese belief of mountains as sacred (Part 1). Komazawa Geography 25: 51-76. (J)

Nagano, T. 1990. Nature preservation in based on the Japanese belief of mountains as sacred (Part 2): A case study of the Ohmine Mountains, Kii Peninsula. Komazawa Geography 26: 67-87. (J)

Nagano, T. 1992a. Nature preservation in based on the Japanese belief of mountains as sacred (Part 3). Journal of the Faculty of Letters of the Komazawa University 50: 1-70. (J)

Nagano, T. 1992b. Sangaku seiikikan ni motozuku sizen goji: Shinshu Togakushiyama no jirei (Nature preservation based on the belief of mountains as sacred: A case of Mt. Togakushi, Shinano Province). Sangaku Shugen 10: 9-23. (J)

Nagano, T. 1995. The mountain belief of Japanese people and its nature conservation. The Journal of Geographical Society of the Hosei University 23: 3-18. (J)

Nagano, T. 1998. Nature conservation in the holy mountain of Japan. Journal of Religious Studies (Komazawa University) 20: 1-36. (J)

Nakagawa, T. 1983. The significance of religious factors in the formation of settlement characteristics: Two settlements on eastern shore of Lake Kasumigaura. The Human Geography 35: 97-113. (JE)

Nakagawa, T. 1991. Kitakanto no ijyu monto shuraku: Bunkato to shiteno approach (A settlement of Shin Buddhist immigrants in the northern part of Kanto region: An approach as a cultural island). In Shutoken no kukan kozo (Metropolitan spatial structure), ed. S. Yamamoto, 150-157. Tokyo: Ninomiya Shoten. (J)

Nakagawa, T. 2005. Spiritual mapping no rironka ni kansuru shukyo tirigakuteki kenkyu (Geographical study of religion about theorization on spiritual mapping). Tsu: Faculty of Humanities and Social Sciences, Mie University. $(J)$

Naylor, S. and Ryan, J. R. 2002. The mosque in the sub- 
urbs: Negotiating religion and ethnicity in South London. Social \& Cultural Geography 3: 39-59.

Nomoto, K. 1990. Kamigami no fukei: Shinko kankyoron no kokoromi (Landscape of gods: An attempt at ecology of beliefs). Tokyo: Hakusuisha. $(\mathrm{J})$

Oda, M. 1989. The formation and its meaning of the 75 -sacred-place view in the Ōmine sacred mountain area. The Human Geography 41: 512-528. (JE)

Oda, M. 2002. Geography of religion in postwar Japan: An analysis of the bibliography. Komazawa Geography 38: 21-51. (JE)

Oguchi, C. 2002. Nihonjin no sotaiteki kankyokan: "Konomarenai kukan" no rekishi chirigaku (Japanese relative view of environment: Historical geography of "unpleasant space"). Tokyo: Kokon-shoin. (J)

Ohira, T. 1996. Grave system in Mino-cho, south-west Japan: In relevance to historical change in villages. The Human Geography 48: 569-583. (J)

Ohira, T. 2003. The possibility of constructionism approach for place. Bulletin of Tokai Women's University 23: 73-83. (J)

Oshiro, N. 1992. Social and historical aspects of landscape: Focused upon ritual facilities in an Okinawan rural settlement. The Historical Geography 159: 2-20. (JE)

Oshiro, N. 1994. Cemeteries and sense of place: A preparatory note for reading the Okinawan landscape. Geographical Review of Japan 67A: 169-182. (JE)

Oshiro, N. 1998. Nationalism to "minzoku" no fukei: Yaeyama no Utaki no episode (The landscape of nationalism and "folklore": Episodes of Utaki in Yaeyama islands). In Kukan kara basho e: Chirigakuteki sozoryoku no tankyu (From space to place: Exploration of geographical imagination), ed. M. Arayama and N. Oshiro, 144-161. Tokyo: Kokon-shoin. (J)

Oshiro, N. 2001. Towards an understanding of "the intensité of place": A methodological argument. Kagoshima University Research Center for the Pacific Islands Occasional Papers 35: 3-12. (JE)

Otani, E. 1995. A note on "immanent interpretation" in the sociology of religion. The Journal of Studies in Contemporary Social Theory 5: 221-231. (J)

Pacione, M. 1999. The relevance of religion for a relevant human geography. Scottish Geographical Journal 115: 117-131.

Park, C. C. 1994. Sacred worlds: An introduction to geography and religion. London: Routledge.

Raivo, P. 2002. The peculiar touch of the East: Reading the post-war landscapes of the Finnish Orthodox Church. Social \& Cultural Geography 3: 11-24.

Sasaki, T. 1989. Religion within the urban landscape. Nihongakuho (Osaka University) 8: 105-128. (JE)

Sasaki, T. 2003. The grounding of imagination: A geographical approach to myth, legend, and folktales. Tokyo: Kokon-shoin. (J)

Semple, E. C. 1911. Influences of geographic environment: On the basis of Ratzel's system of anthropo-geography. New York: Henry Holt.

Shimazono, S. 1992a. Gendai kyusai shukyo ron (Theory of modern salvational religion). Tokyo: Seikyusha. (J)

Shimazono, S. 1992b. Shukyo rikai to kyakkansei (Comprehension of religion and objectivity). In Ima shukyo wo dou toraeruka (How to understand religion now?), ed. Shukyo Shakaigaku Kenkyukai, 108-126. Tokyo: Kaimeisha. (J)

Shimazono, S. 1996. New spirituality movements in the global society. Tokyo: Tokyodo Shuppan. (J)

Shimazu, T. 1990. Pilgrimage place system and rural communities: A case study in Japan. The Historical Geography 151: 1-15. (JE)

Slater, T. R. 2004. Encountering God: Personal reflection on "geographer as pilgrim". Area 36: 245-253.

Sonoda, M. 1990. Matsuri no genshogaku (Phenomenology of festivals). Tokyo: Kobundo. (J)

Sonoda, M. 1995. The religious nature of a social-ecological system. Journal of Religious Studies 304: 135-156. (JE)

Sopher, D. E. 1967. Geography of religions. Englewood Cliffs: Prentice-Hall.

Sopher, D. E. 1981. Geography and religion. Progress in Human Geography 5: 510-524.

Stump, R. W. 1986. Introduction. Journal of Cultural Geography 7(1): 1-3.

Stump, R. W. 2000. Boundaries of faith: Geographical perspectives on religious fundamentalism. Lanham: Rowmans and Littlefield Publishers.

Suizu, I. 1959. Geography of parishes in Germany. The Journal of the Literary Association of Osaka City University 10: 177-200. (J)

Suzuki, M. 1999. Daichi kara kami e (From ground to god). In Daichi to kamigami no kyosei: Sizen kankyo to shukyo (Coexistence of ground and god: Natural environment and religion), ed. M. Suzuki, 5-28. Kyoto: Showado. (J)

Taira, S. 2002. The "landscape" and Imago Mundi: Reinterpretation of the sacred landscape of "Ou" in Okinawa islands. Studies in Philosophy (University of Tsukuba) 27: 131-151. (JE)

Tamura, T. 1999. A view point for studies of CMC and religion. Tsukuba Annals of Sociology 11: 19-41. 
(JE)

Tong, C. K. and Kong, L. 2000. Religion and modernity: Ritual transformations and the reconstruction of space and time. Social \& Cultural Geography 1: 29-44.

Tuan, Y. 1976. Humanistic geography. Annals of the Association of American Geographers 66: 266-276.

Tuan, Y. 1977. Space and place: The perspective of experience. Minneapolis: University of Minnesota Press.

Tuan, Y. 1978. Sacred space: Exploration of an India. In Dimensions of human geography: Essays on some familiar and neglected themes, ed. K. W. Butzer, 84-99. Chicago: University of Chicago, Department of Geography.

Uchida, H. 1971. Nihon no shukyoteki fudo to kokudokan (The religious climate and the view of country in Japan). Tokyo: Taimeido. (J)

Ueda, M. ed. 2004. Tankyu "Chinju no mori": Shasougaku eno shoutai (Exploration of forests in shrines: Introduction to the study of forests in shrines). Tokyo: Heibonsha. (J)

Ueda, M. and Ueda, A. eds. 2001. Chinju no mori wa yomigaeru: Shasougaku kotohajime (Revival of the forests in shrines: Introduction to the study of forests in shrines). Kyoto: Shibunkaku Shuppan. (J)

Watsuji, T. 1979 [1935]. Fudo (Climate and culture). Tokyo: Iwanami Shoten. (J)

Wilson, D. 1993. Connecting social process and space in the geography of religion. Area 25: 75-76.

Yagi, Y. 1998. Minzoku sonraku no kukan kozo (Spatial structure of folk village). Tokyo: Iwatashoin. (J)

Yamaguchi, Y. 1997. Landscape structure of a sacred basin village, Murō: Paying attention to a landscape attracting human beings. The Human Geography 49: 159-174. (JE)

Yoshida, T. 1987. Culture. In Bunka jinruigaku jiten (The dictionary of cultural anthropology), ed. E. Ishikawa, T. Umesao, T. Obayashi, M. Gamoh, K. Sasaki, and T. Sofue, 666-667. Tokyo: Kobundo. (J)

$(J)$ : written in Japanese

(JE): written in Japanese with English abstract 